\title{
Development of Learning Media Swimming Freestyle Based on Macromedia Flash 8 on Students Class VIII SMPN 2 Padang
}

\section{Meiriani Armen ${ }^{1}$ and Ade Fitri Rahmadani² \\ ${ }^{1}$ Physical education of health and recreation, Bung Hatta University \\ ${ }^{2}$ Education Technology and Computer Science, Bung Hatta University}

\section{Abstract}

The purpose of this research study produces instructional media in the form of $C D$ subjects sports physical Education freestyle swimming material using a computer. In junior high school the method of learning used lectures and command methods, due to the condition and lack of adequate learning media availability. This study aims to produce aspects of performance and programming aspects of learning media in the form of $C D$ processed in the form of macromedia flash 8 in order to produce a

Corresponding Author: Meiriani Armen

ria.pjkr12@bunghatta.ac.id

Received: 18 January 2019 Accepted: 24 March 2019 Published: 31 March 2019

Publishing services provided by Knowledge E

(c) Meiriani Armen and Ade Fitri Rahmadani. This article is distributed under the terms of the Creative Commons

Attribution License, which permits unrestricted use and redistribution provided that the original author and source are credited.

Selection and Peer-review under the responsibility of the ICEST 2018 Conference Committee. more interesting media in the subjects sports physical Education and health freelance pool material by using the computer, in accordance with the appropriate development stages, resulting in useful and quality learning media. Methode research belongs to methode research and development. Research steps: introduction, development of learning design, product design development, evaluation and revision. After going through the stages of production then validated by a media expert. The test subjects are students of SMPN 2 Padang who have obtained freestyle swimming material. Data obtained through the provision of questionnaires to media experts in the form of assessment results on aspects of appearance and programming aspect. The results obtained from the media experts from the aspect of the display is "very good" with the average score of 4.38 . From the aspect of programming the results obtained "very good" with the average score of 4.8 . It can be concluded that the display and programming of free-style pool learning media is "very good" and can be used by VII junior high school students.

Keywords: learning media, freestyle pool, Macromedia flash 8

\section{Introduction}

Physical education is a process of learning through physical activity designed to improve physical fitness, develop motor skills, knowledge, healthy living behavior, active, sportive attitude and emotional intelligence (Adun Sudijandoko, 2010: 4). In physical education 
learning activities there are two processes that take place are teaching activities and learning activities. In this learning activity occurs interaction between teacher and student. This interaction process involves the teacher as a source of information and students as a subject learn. Teachers will teach materials according to the applicable curriculum. The material to be taught must be planned in such a way that the learning objectives are achieved, (Herka Maya Jatmika, 2005).

Utilization of media is integral in learning. Learning media, according to Kemp (1994: 28) can fulfill three main functions if the media is used for individuals, groups, groups of listeners of a large number that is: (1) motivate interest or action, (2) present information, (3) give instructions. To fulfill the function of motivating the media can be realized with drama and entertainment techniques. With the media is expected to improve the quality of learning and facilitate teachers and learners to achieve educational goals. Benefits that can be taken from the use of media according to Oemar Hamalik (1994: 18) is the media can generate motivation and psychological effects for learners.

Swimming sport is one of the materials taught on the subject of Physical Education of Sports and Health in junior high. According to Abdoelah Arma (1981: 270) Definition of swimming is a type of exercise done in water, either in freshwater maupuan in salt water or sea. This swimming material is given in the form of materials theory and practice, in learning activities, students are expected to master the freestyle pool in accordance with the material taught on each semester and a certain level. According to Kurnia Dadeng (1987) the pool is divided into 4 categories, namely: free style, breaststroke, butterfly style and backstroke. Of the four styles freestyle is the basic style given to the students / learners in the learning process pool, because movement techniques are more easily taught. Keep in mind that before starting the basic techniques of freestyle swimming students / learners need to do water recognition.

Free style is the style of swimming with the position of the head tengkurep enter in the water. Straight body position of the foot down but will not bend but with a straight leg position. The hand paddles in turn alternately and breathes right or left by turning to the right or left. Position the face out of the water surface. There are areas of free-force concentration (crawl) that is (1). Body attitude (2). Foot movement (3). Arm movement (4). Breathe (5). coordination of motion (Rob, C Orr and Jane B. Tyler (2008: 14).

The next problem is about the utilization of school facilities as a medium of learning that has not been optimal. The existence of a computer laboratory has not been used as an alternative place to learn besides outside the classroom, computer laboratory is only used for ICT learning only, whereas there are opportunities to be utilized sports learning, with statement above school need interactive learning media to complete the 
learning process in the classroom especially penjasorkes (sport). With the help of visual media such as pictures of people swimming with the stages of the students will more easily accept the concept that is taught to be implemented.

Based on the above problems then one of the efforts to accomplish through the media using macromedia flash 8 learning this software because it is able to display a combination of text, images, animation, audio, and video to clarify the subject matter, this certainly can not be obtained if using the media book. Utilization of computer-based learning media with macromedia flash 8 as a tool for creating, designing and running media. Macromedia flash 8 application program is one software that can be specially designed to display an interesting multimedia program in learning in the classroom. According Rayandra Asyar (2012: 73) says, "video media can be classified as audiovisual media. Innovation by teachers to make learning in the classroom more interesting is by utilizing several programs that are able to produce an interactive learning media. One of the programs used in this learning media Macromedia Flash. According to Ariesto Hadi Sutopo (2003: 60). Although the physical form is different, this media has similarities with the film, which is equally capable of displaying moving images. It can be concluded that the need for the application of appropriate instructional media or the model used to improve the basic motion skills of SMP Student freestyle pool. Learning media oriented on the principle of learning tailored to the stage of student growth and development as well as modify the time and process of learning are expected to improve the basic motion skills freestyle pool so as to provide fresh air for students so motivated to carry out learning penjasorkes in schools, free.

In the stage of development, junior high school students are estimated to be at the stage of development period of 13-15 years old, according to Sukintaka (1992: 64). It can be concluded that the characteristics of junior high school students of class VIII have characteristics such as rapid physical growth, sexual development, causality, emotion, and interest in the opposite sex, This can be simplified as a period of puberty that has many unique features. Judging from the cognitive abilities of early teens mentioned above, the learning media in the form of CDs containing materials about the free-style pool will be accepted by students without experiencing significant obstacles.

In displaying the learning media can be seen from two aspects, namely aspects of media display and aspke pemograman media. The formulation of the problem in this research is the display and pemrograman learning media freestyle based on macromedia flash 8 for students of class VII SMP. 


\section{Research Methodology}

The design is a research and development (research and development). In this study the product developed is a source of learning based on macromedia flash 8 for subjects of Physical Education Sport and Health, freestyle swimming material for Junior High School (SMP). Research subjects are media experts and students of class VII in the semester of January-June 2018 at SMPN 2 Padang.

Research instrument developed to collect data in this research is Data obtained is quantitative data that will be converted into qualitative data. The data can provide an overview of the quality of the material both content, appearance, and strategies in learning. Sheet assessment instrument by the media expert in the form of a questionnaire consisting of two aspects of assessment that aspects of appearance and programming aspect. The instrument sheet in the form of product validation results was obtained using questionnaires and evaluation sheets.

Indicator The achievement in this research is: the aspect of display and programming of Learning Media in the form of Compact Disc (CD) learning of free flash material based on multimedia 8 in First VII High School.

The steps taken in data analysis include: Collecting rough data. Scoring. The scores obtained are then converted to scale 5 (Jaliusril, Rayandra Asyhar, Hary Soedarto Harjono. (2012) using the following conversion terms:

TABLE 1: Assessment Criteria.

$\begin{array}{ll}\text { Criteria } & \text { Skor Interval } \\ \text { Very good } & X>X i+1,8 \text { Sbi } \\ \text { Good } & X i+0,6 S b i<X \leq X i+1,8 \text { Sbi } \\ \text { Good enough } & X i-0,6 S b i<X \leq X i+0,6 S b i \\ \text { Less good } & X i-1,8 S b i<X \leq X i-0,6 S b i \\ \text { Very less good } & X \leq X i-1,8 S b i\end{array}$

\section{Results and Discussion}

The revised product expert of media stage 1 says there is no usage page. Usage instructions should be made, making it easier for students to use instructional media. Profile icons are made more formal, there are photo creators and media. Problems are made based on existing material, in order to facilitate students in answering questions questions. Each of the displayed materials is accompanied by a clear and quite contrasting 
image visible to the students. Menu color and background media made more interesting, with the aim of students more interesting in learning through this media. Once revised in stage 1, where media experts provide input and additions to better developed media. So when done phase 2 revision, media experts say it is perfect and worthy to be tested to students. Multiple media view macromedia flash8 freeware style pools that have been revised by media experts:

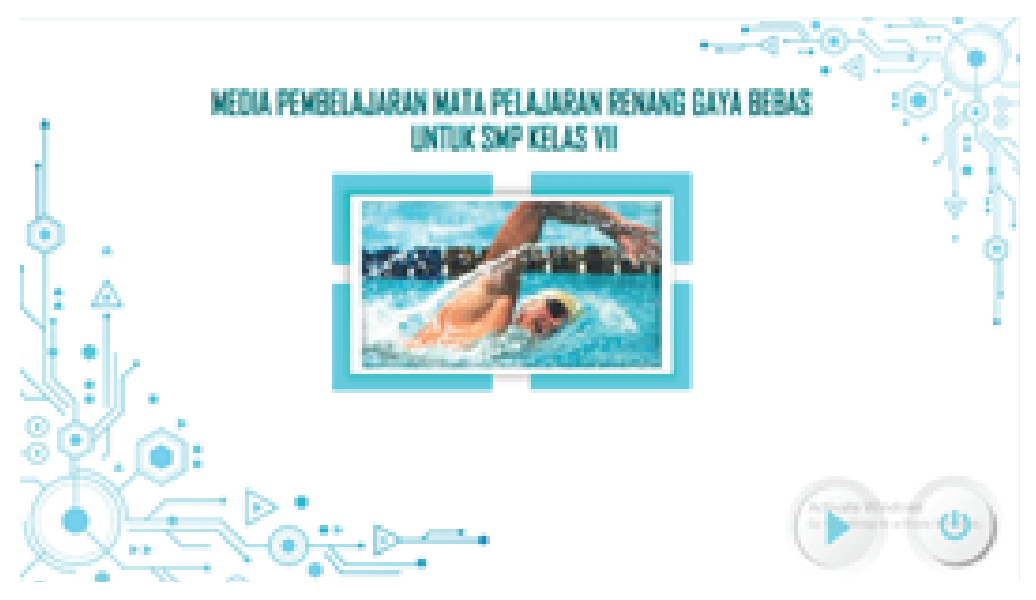

Figure 1: Title page.

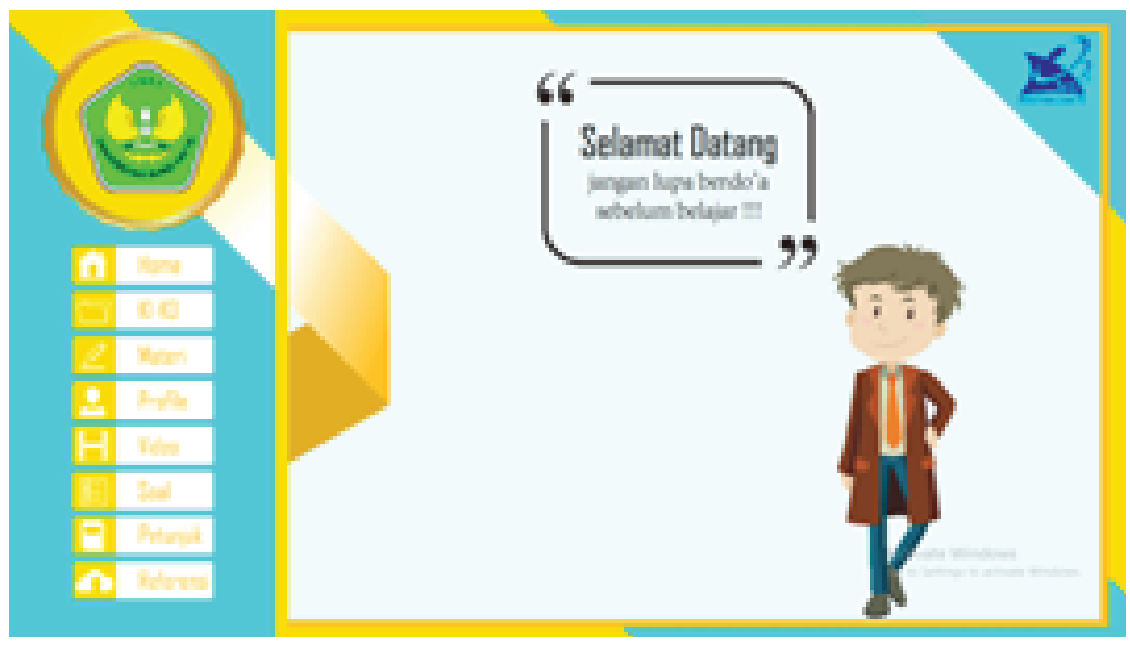

Figure 2: The menu page.

The revised product descriptions and questionnaires before the media are feasible to be tested as follows: Learning media products and questionnaires were given on April 4, 2018. Media experts provided a first stage assessment of the display aspects of instructional media with a mean score of 3.52 included in the "good" category for more details can be seen in the table as follows: 


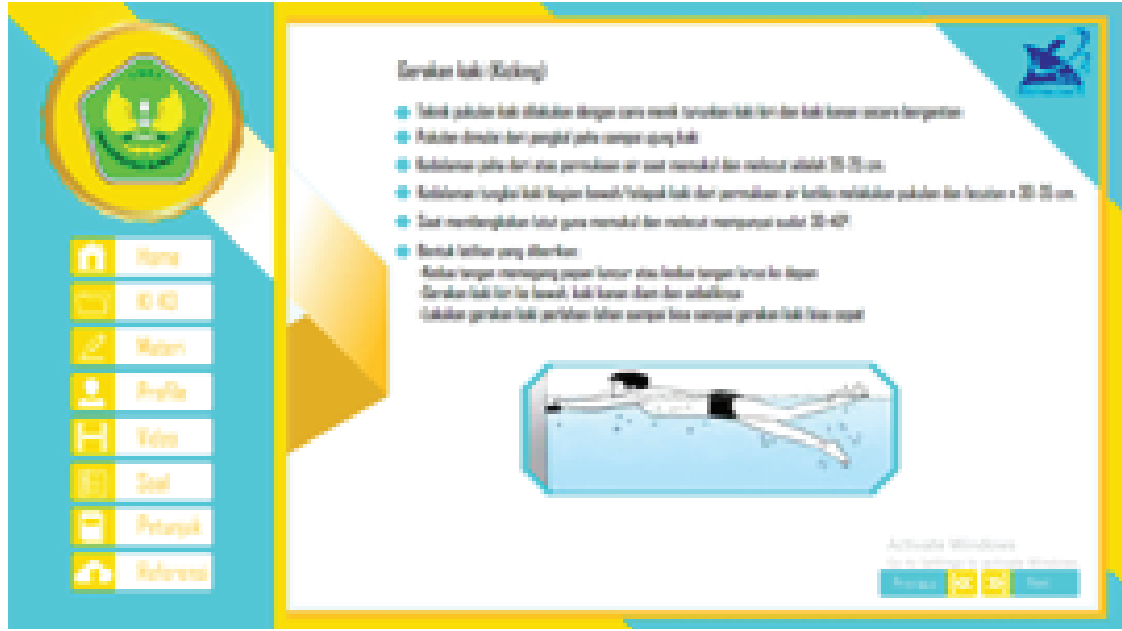

Figure 3: material page.

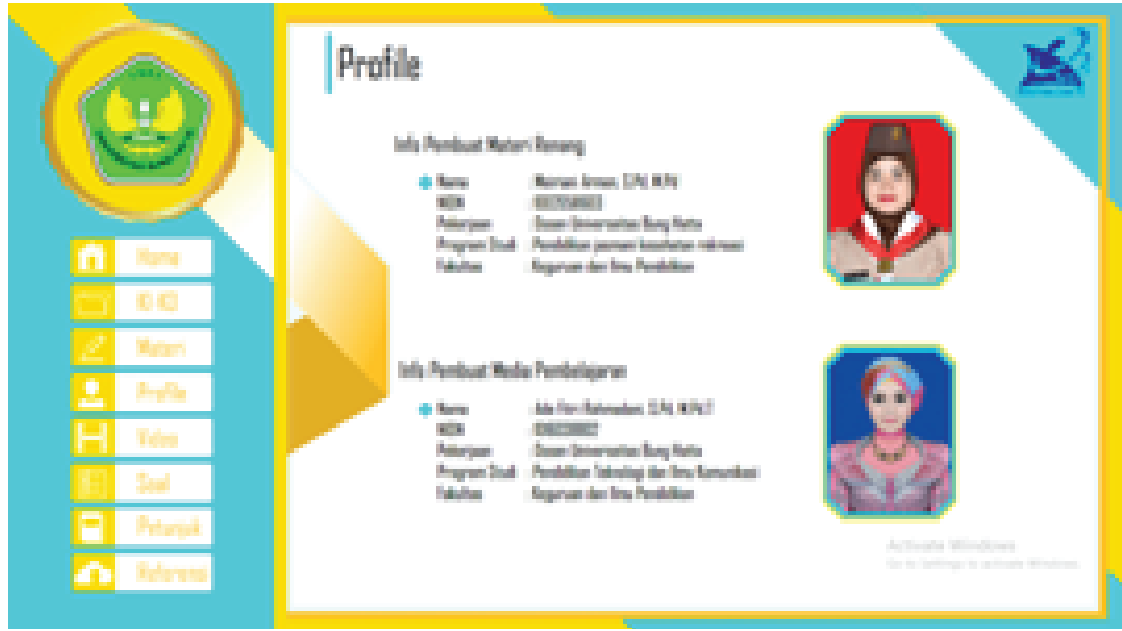

Figure 4: Profile page.

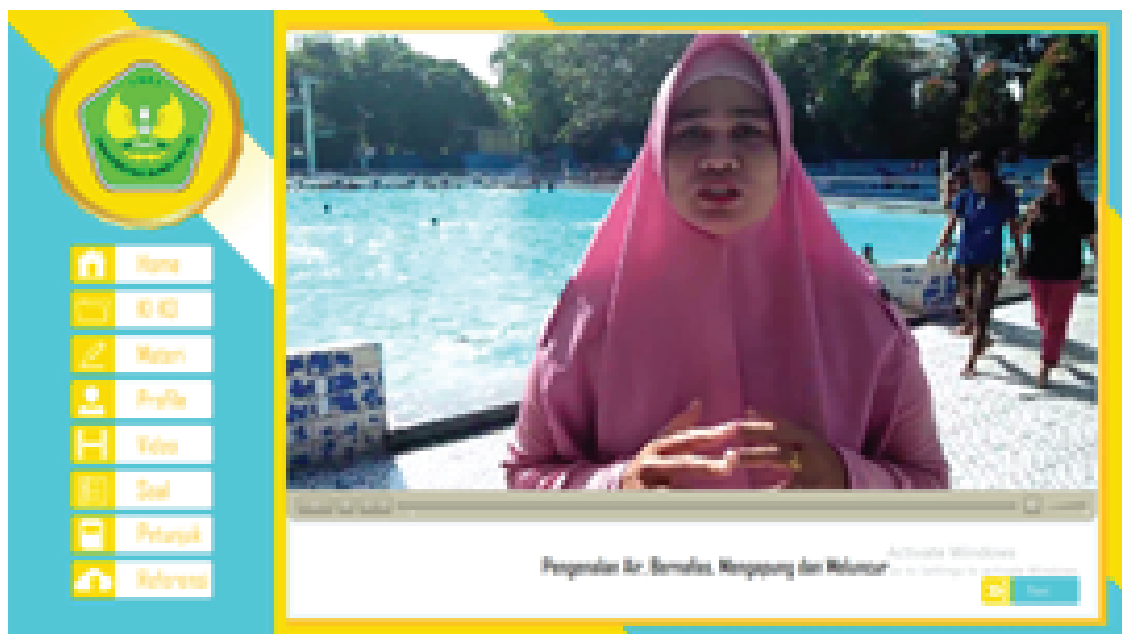

Figure 5: video introduction of water. 


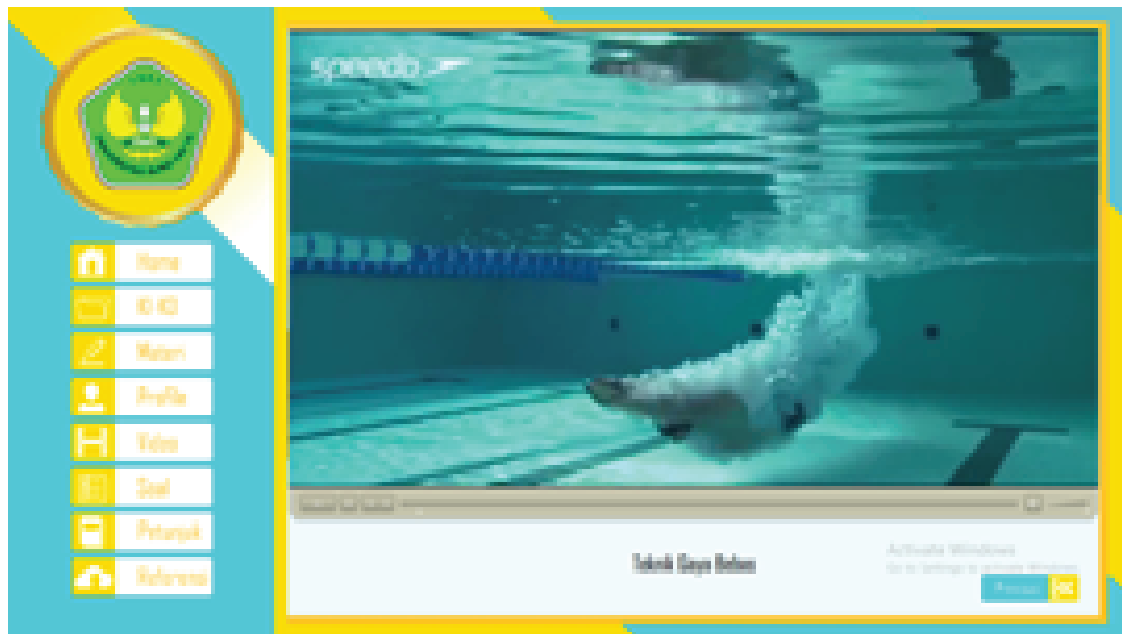

Figure 6: Freestyle swimming video.

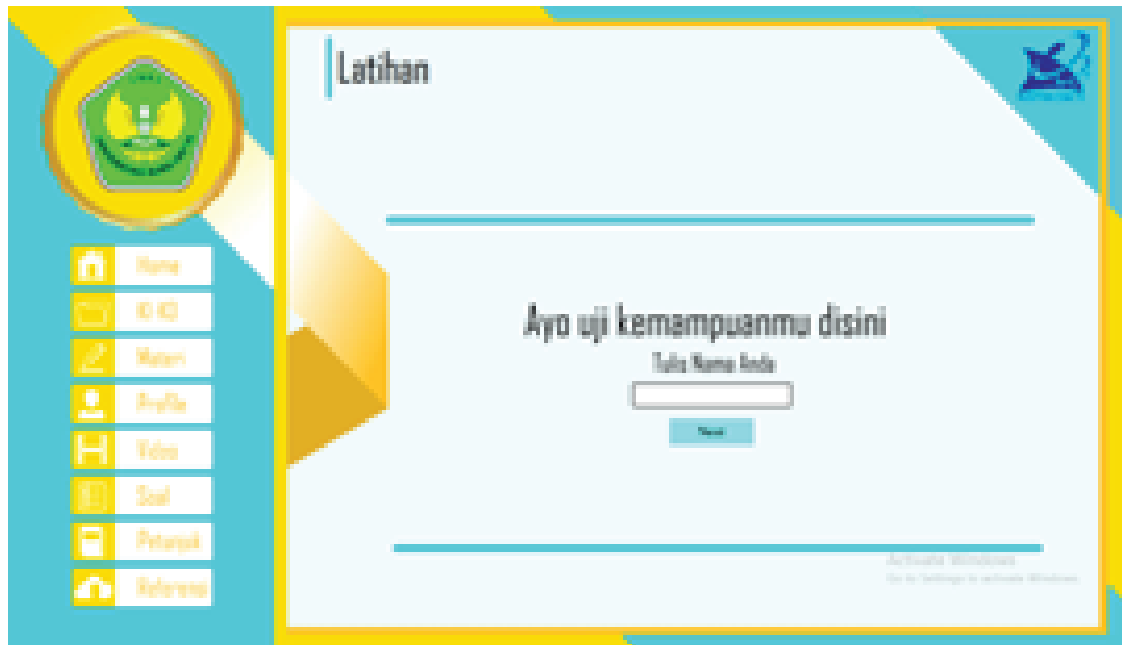

Figure 7: question page.

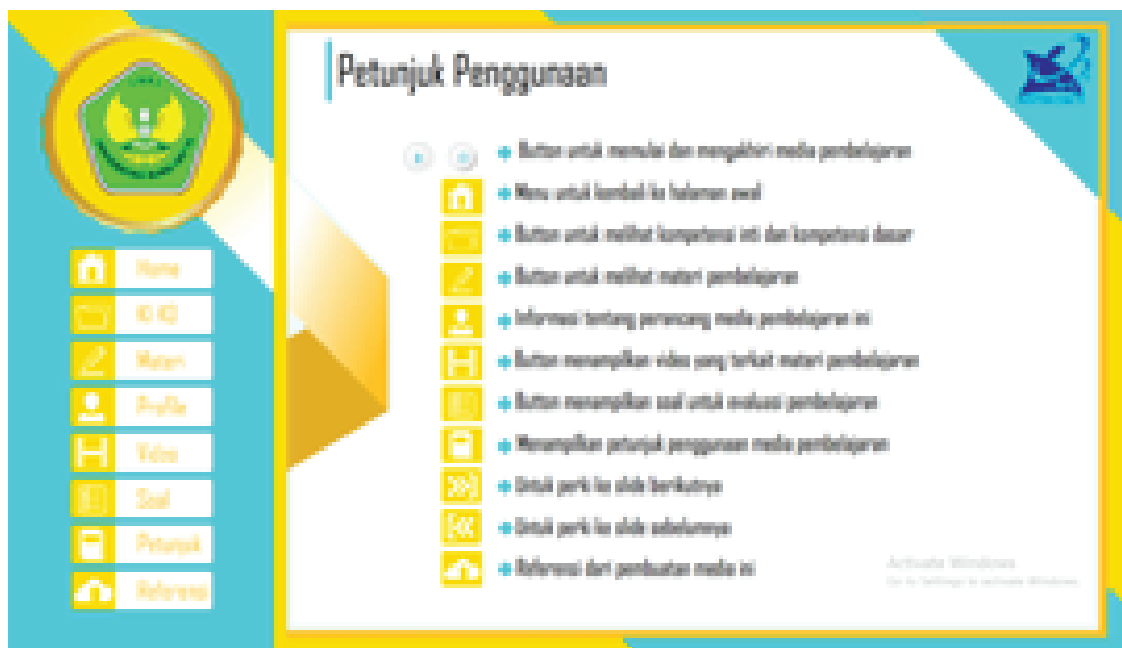

Figure 8: instructions for use. 
TABLE 2: Score Aspects of Display From Media Experts (Phase I).

\begin{tabular}{|c|c|}
\hline No & Rate Aspect \\
\hline 1 & The accuracy of color selection (Background) \\
\hline 2 & The suitability of writing color and Background \\
\hline 3 & The accuracy of choosing music \\
\hline 4 & Interesting animation \\
\hline 5 & Clarity of animation \\
\hline 6 & Video clarity \\
\hline 7 & Clarity of narration \\
\hline 8 & Video size \\
\hline 9 & Relevate video with material \\
\hline 10 & Button placement \\
\hline 11 & Consistency of the button \\
\hline 12 & Button size \\
\hline 13 & The accuracy of button color selection \\
\hline 14 & The accuracy of text color selection \\
\hline 15 & Accurate selection of fonts \\
\hline 16 & Accuracy of font size \\
\hline 17 & Image clarity \\
\hline 18 & Image color clarity \\
\hline 19 & Image size clarity \\
\hline 20 & Slide design view \\
\hline \multirow[t]{4}{*}{21} & The composition of each slide \\
\hline & amount \\
\hline & Total score \\
\hline & Average \\
\hline
\end{tabular}

\begin{tabular}{|c|c|c|c|c|c|}
\hline \multicolumn{5}{|c|}{ Scoring Scale } & \multirow[t]{2}{*}{ Criteria } \\
\hline 1 & 2 & 3 & 4 & 5 & \\
\hline & & & $\sqrt{ }$ & & Good \\
\hline & & & $\sqrt{ }$ & & Good \\
\hline & & $\sqrt{ }$ & & & $\begin{array}{l}\text { Good } \\
\text { Enough }\end{array}$ \\
\hline & & & $\sqrt{ }$ & & Good \\
\hline & & $\sqrt{ }$ & & & $\begin{array}{l}\text { Good } \\
\text { Enough }\end{array}$ \\
\hline & & $\sqrt{ }$ & & & $\begin{array}{l}\text { Good } \\
\text { Enough }\end{array}$ \\
\hline & & & $\sqrt{ }$ & & Good \\
\hline & & & $\sqrt{ }$ & & Good \\
\hline & & & $\sqrt{ }$ & & Good \\
\hline & & $\sqrt{ }$ & & & $\begin{array}{l}\text { Good } \\
\text { Enough }\end{array}$ \\
\hline & & $\sqrt{ }$ & & & $\begin{array}{l}\text { Good } \\
\text { Enough }\end{array}$ \\
\hline & & $\sqrt{ }$ & & & $\begin{array}{l}\text { Good } \\
\text { Enough }\end{array}$ \\
\hline & & & $\sqrt{ }$ & & Good \\
\hline & & & $\sqrt{ }$ & & Good \\
\hline & & & $\sqrt{ }$ & & Good \\
\hline & & & $\sqrt{ }$ & & Good \\
\hline & & $\sqrt{ }$ & & & $\begin{array}{l}\text { Good } \\
\text { Enough }\end{array}$ \\
\hline & & & $\sqrt{ }$ & & Good \\
\hline & & $\sqrt{ }$ & & & $\begin{array}{l}\text { Good } \\
\text { Enough }\end{array}$ \\
\hline & & $\sqrt{ }$ & & & $\begin{array}{l}\text { Good } \\
\text { Enough }\end{array}$ \\
\hline & & $\sqrt{ }$ & & & $\begin{array}{l}\text { Good } \\
\text { Enough }\end{array}$ \\
\hline & & 30 & 44 & & Good \\
\hline & & 74 & & & \\
\hline & & 3.52 & & & \\
\hline
\end{tabular}


While on the aspect pemograman, media experts provide supervision with the average score of valuation with the average of 3.5 included in the category of "good". For more details can be seen in table 10 as follows:

TABLE 3: Score Aspects of Programming from Media Experts stage 1.

\begin{tabular}{|l|l|}
\hline No & Rate Aspect \\
\hline 1 & Interactive level of students \\
\hline 2 & Ease of using media \\
\hline 3 & Clarity of usage instructions \\
\hline 4 & Clarity of navigation structure \\
\hline 5 & Ease of use of the button \\
\hline 6 & Accuracy of animation \\
\hline 7 & Arrange animation \\
\hline 8 & Providing feedback on student responses \\
\hline 9 & Text Efficiency \\
\hline 10 & Use of slides \\
\hline amount
\end{tabular}

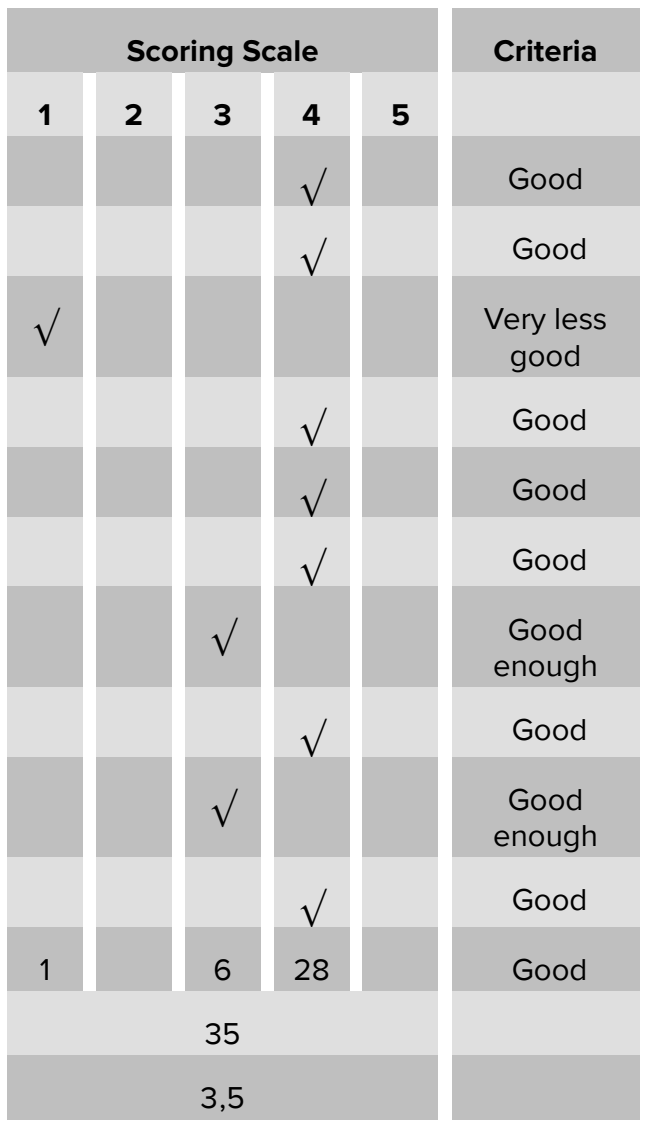

The questionnaire and learning media developed were given on April 18, 2018, on the second phase validation. Media experts gave an assessment of the aspect of the display with the average score of 4.38 included in the "excellent" category and the data can be seen in the following table:

In this second phase validation, media experts give value from the quality of learning media viewed from the aspect of display and programming, that is the quality of media is good and perfect. Can proceed at a later stage. The final conclusion of this instructional media is worthy of a trial without revision.

\subsection{Data analysis from media expert validation results}

Data from media experts can be obtained from providing a questionnaire that contains aspects of the display and programming aspect. The data obtained from the first and 
TABLE 4: Aspect Display Scores From Media Experts (Phase II).

\begin{tabular}{|c|c|c|c|c|c|c|c|}
\hline \multirow[t]{2}{*}{ No } & \multirow[t]{2}{*}{ Rate Aspect } & \multicolumn{5}{|c|}{ Scoring Scale } & \multirow[t]{2}{*}{ Criteria } \\
\hline & & 1 & 2 & 3 & 4 & 5 & \\
\hline 1 & The accuracy of color selection (Background) & & & & $\sqrt{ }$ & & Good \\
\hline 2 & The suitability of writing color and Background & & & & & $\sqrt{ }$ & Very good \\
\hline 3 & The accuracy of choosing music & & & & $\sqrt{ }$ & & Good \\
\hline 4 & Interesting animation & & & & $\sqrt{ }$ & & Good \\
\hline 5 & Clarity of animation & & & & $\sqrt{ }$ & & Good \\
\hline 6 & Video clarity & & & & & $\sqrt{ }$ & Very good \\
\hline 7 & Clarity of narration & & & & & $\sqrt{ }$ & Very good \\
\hline 8 & Video size & & & & & $\sqrt{ }$ & Very good \\
\hline 9 & Relevate video with material & & & & & $\sqrt{ }$ & Very good \\
\hline 10 & Button placement & & & & $\sqrt{ }$ & & Good \\
\hline 11 & Consistency of the button & & & & $\sqrt{ }$ & & Good \\
\hline 12 & Button size & & & & $\sqrt{ }$ & & Good \\
\hline 13 & The accuracy of button color selection & & & & $\sqrt{ }$ & & Good \\
\hline 14 & The accuracy of text color selection & & & & $\sqrt{ }$ & & Good \\
\hline 15 & Accurate selection of fonts & & & & $\sqrt{ }$ & & Good \\
\hline 16 & Accuracy of font size & & & & $\sqrt{ }$ & & Good \\
\hline 17 & Image clarity & & & & & $\sqrt{ }$ & Very good \\
\hline 18 & Image color clarity & & & & $\sqrt{ }$ & & Good \\
\hline 19 & Image size clarity & & & & $\sqrt{ }$ & & Good \\
\hline 20 & Slide design view & & & & & $\sqrt{ }$ & Very good \\
\hline \multirow[t]{4}{*}{21} & The composition of each slide & & & & & $\sqrt{ }$ & Very good \\
\hline & Amount & & & & 52 & 40 & Very good \\
\hline & Total score & \multicolumn{5}{|c|}{92} & \\
\hline & Average & \multicolumn{5}{|c|}{4,38} & \\
\hline
\end{tabular}

second stage validation are dianilasis and used as the basis for revising the learning media product that has been developed. 
TABLE 5: Skor Aspek of Programming from media expert phase II.

\begin{tabular}{|c|c|c|c|c|c|c|c|}
\hline \multirow[t]{2}{*}{ No } & \multirow[t]{2}{*}{ Rate Aspect } & \multicolumn{5}{|c|}{ Scoring Scale } & \multirow[t]{2}{*}{ Criteria } \\
\hline & & 1 & 2 & 3 & 4 & 5 & \\
\hline 1 & Interactive level of students & & & & $\sqrt{ }$ & & Good \\
\hline 2 & Ease of using media & & & & & $\sqrt{ }$ & Very good \\
\hline 3 & Clarity of usage instructions & & & & & $\sqrt{ }$ & Very good \\
\hline 4 & Clarity of navigation structure & & & & & $\sqrt{ }$ & Very good \\
\hline 5 & Ease of use of the button & & & & & $\sqrt{ }$ & Very good \\
\hline 6 & Accuracy of animation & & & & & $\sqrt{ }$ & Very good \\
\hline 7 & Arrange animation & & & & $\sqrt{ }$ & & Good \\
\hline 8 & Providing feedback on student responses & & & & & $\sqrt{ }$ & Very good \\
\hline 9 & Text Efficiency & & & & & $\sqrt{ }$ & Very good \\
\hline \multirow[t]{4}{*}{10} & Use of slides & & & & & $\sqrt{ }$ & Very good \\
\hline & Amount & & & & 8 & 40 & Very good \\
\hline & Score & \multicolumn{5}{|c|}{48} & \\
\hline & Average & \multicolumn{5}{|c|}{4,8} & \\
\hline
\end{tabular}

\subsubsection{Phase I}

In phase I Based on the data obtained from the assessment of media experts stage I on the aspect of display consisting of 21 items contained in the questionnaire is "good" with the average score of 3.52, whereas in the assessment of media experts on programming aspect consisting of 10 items including in the "good" criterion with a mean of 3.5 scores. Average on the overall aspect of the display is 3.52 included in the "good" criteria. The following is the frequency table and bar chart of the assessment of the display aspect by the stage I media experts.

TABLE 6: Frequency of Assessment of Quality Display Aspect by Media Expert Phase I.

\begin{tabular}{l|c|c|}
\hline Criteria & Frekuensi & $\%$ \\
\hline Very good & 0 & 0 \\
\hline Good & 11 & $52,39 \%$ \\
\hline Good enough & 10 & 47,61 \\
\hline Less good & 0 & 0 \\
\hline Very less good & 0 & 0 \\
\hline Amount & 21 & $100 \%$ \\
\hline
\end{tabular}


For more details can be seen in the following bar chart image:

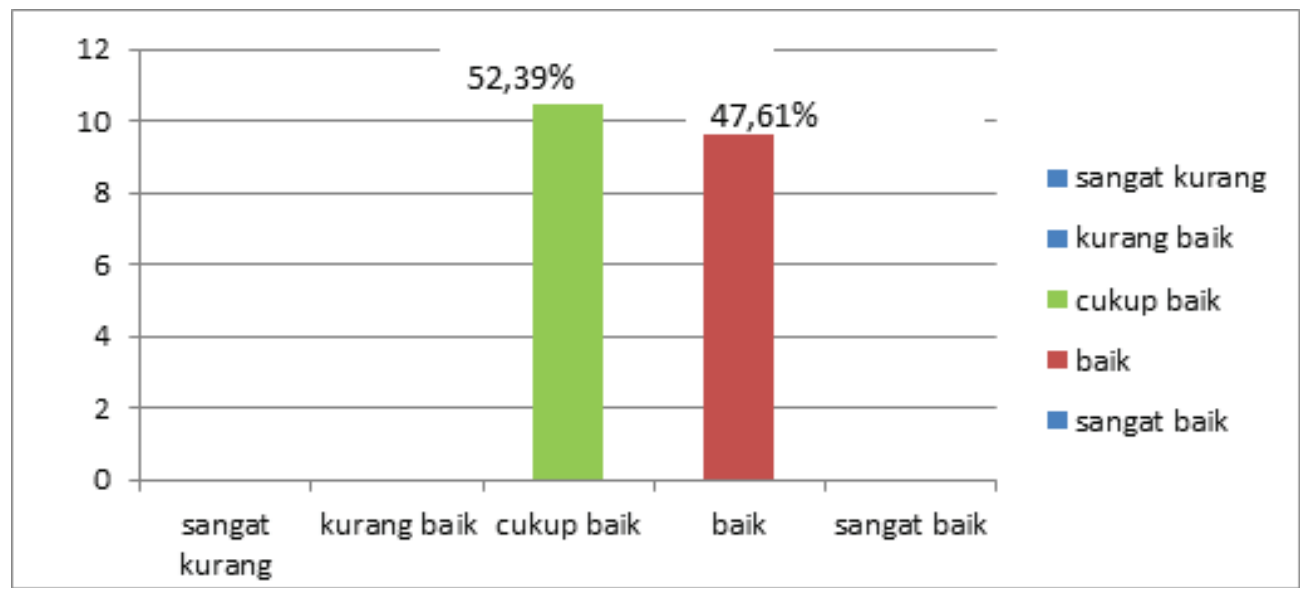

Figure 9: Histogram Aspect Display Media Expert Phase I.

While for aspect pemograman consisting of 10 item "good" with mean score 3,5. For more details can be seen in the following table frequency and bar charts:

TABLE 7: Frequency of Assessment of Aspect of Programming Quality of Media Expert Phase I.

\begin{tabular}{|l|c|c|}
\hline Kriteria & Frekuensi & $\%$ \\
\hline Very good & 0 & 0 \\
\hline Good & 7 & $70 \%$ \\
\hline Good enough & 2 & $20 \%$ \\
\hline Less good & 0 & 0 \\
\hline Very less good & 1 & $10 \%$ \\
\hline Amount & 10 & $100 \%$ \\
\hline
\end{tabular}

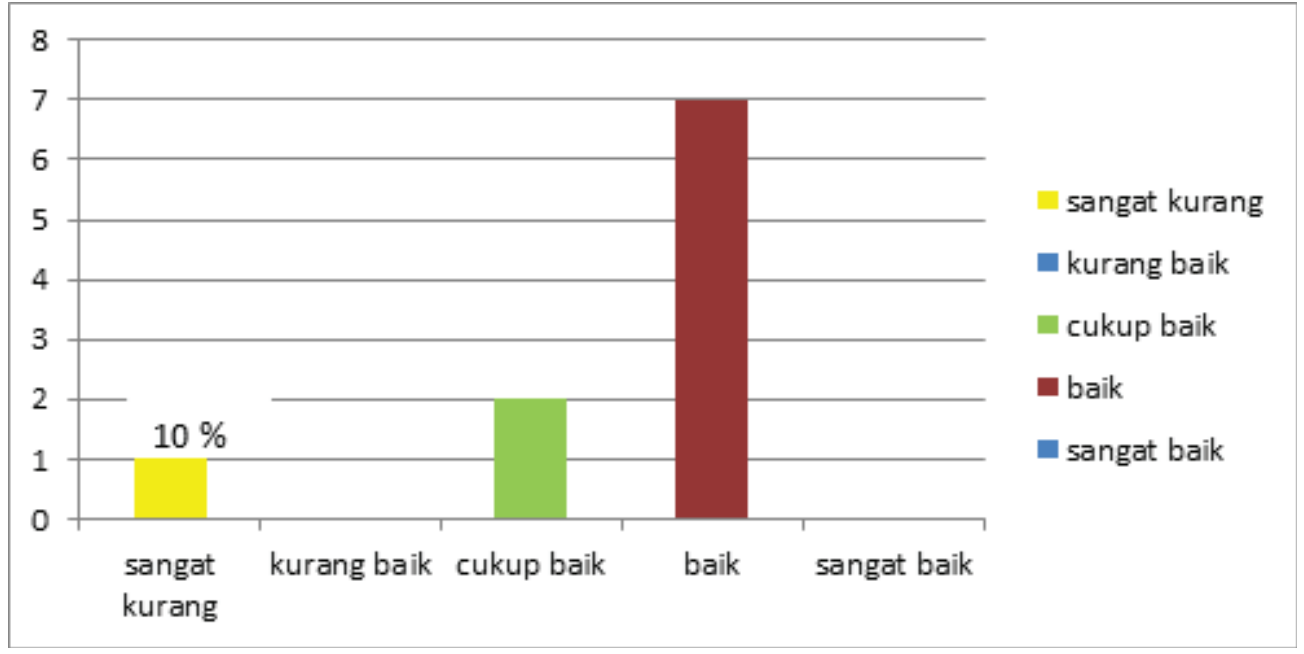

Figure 10: Histogram Aspect of Programming Expert of Media Phase I. 
TABLE 8: Product Quality Learning Media Expert Results Media Phase I.

\begin{tabular}{|l|c|c|}
\hline Rated aspect & average & Criteria \\
\hline Display aspect & 3,52 & Good \\
\hline Aspects of programming & 3,50 & Good \\
\hline Average & $\mathbf{3 , 5 1}$ & Good \\
\hline
\end{tabular}

Here's a picture of the stem graph assessment of product quality media learning by media experts stage I.

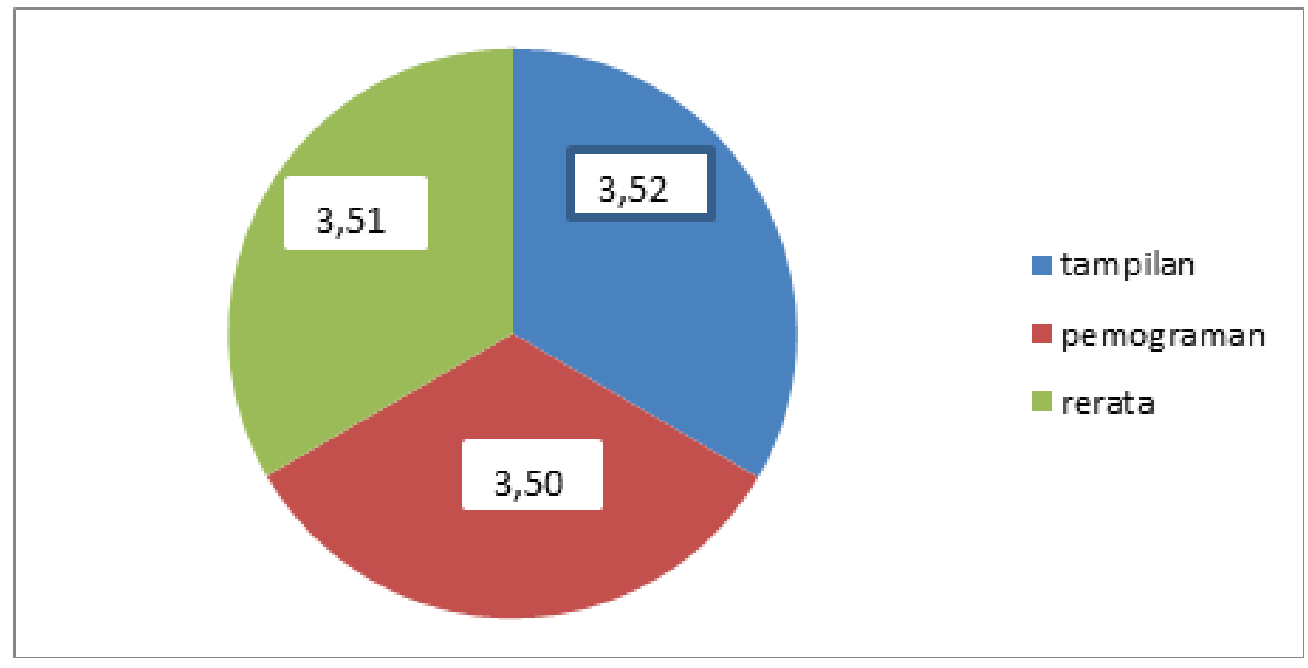

Figure 11: Histogram Product Quality Learning Media.

\section{Validation Results By Media Experts Stage I}

Based on the above data can be seen that the results of expert assessment of media stage I of the quality of learning media products under development is included in the category of "good". The average score on the aspect of display and programming aspect is 3.51. In addition, media experts provide suggestions, feedback on media content that has been developed to improve the learning media. All inputs and suggestions / comments are recorded and made into materials to revise the product, so that the quality of the product developed is even better.

\subsubsection{Phase II}

After the revised learning media product is then validated in the second stage. From the second stage validation, data on the quality of instructional media developed in the display aspect consisting of 21 items are included in the "excellent" category with the 
average score of 4.38 . While the programming aspect consisting of 10 items categorized "very good" with the average score of 4.80 . Here is the frequency distribution table and histogram of the assessment results from the aspect of display in stage II.

TABLE 9: Frequency Aspects of the Quality of Media Expert View Phase II.

\begin{tabular}{|l|c|c|}
\hline Kriteria & Frekuensi & $\%$ \\
\hline Very good & 8 & 38,10 \\
\hline Good & 13 & 61,90 \\
\hline Good enough & 0 & 0 \\
\hline Less good & 0 & 0 \\
\hline Very less good & 0 & 0 \\
\hline Amount & 21 & 100 \\
\hline
\end{tabular}

For more details can be seen on the following histogram:

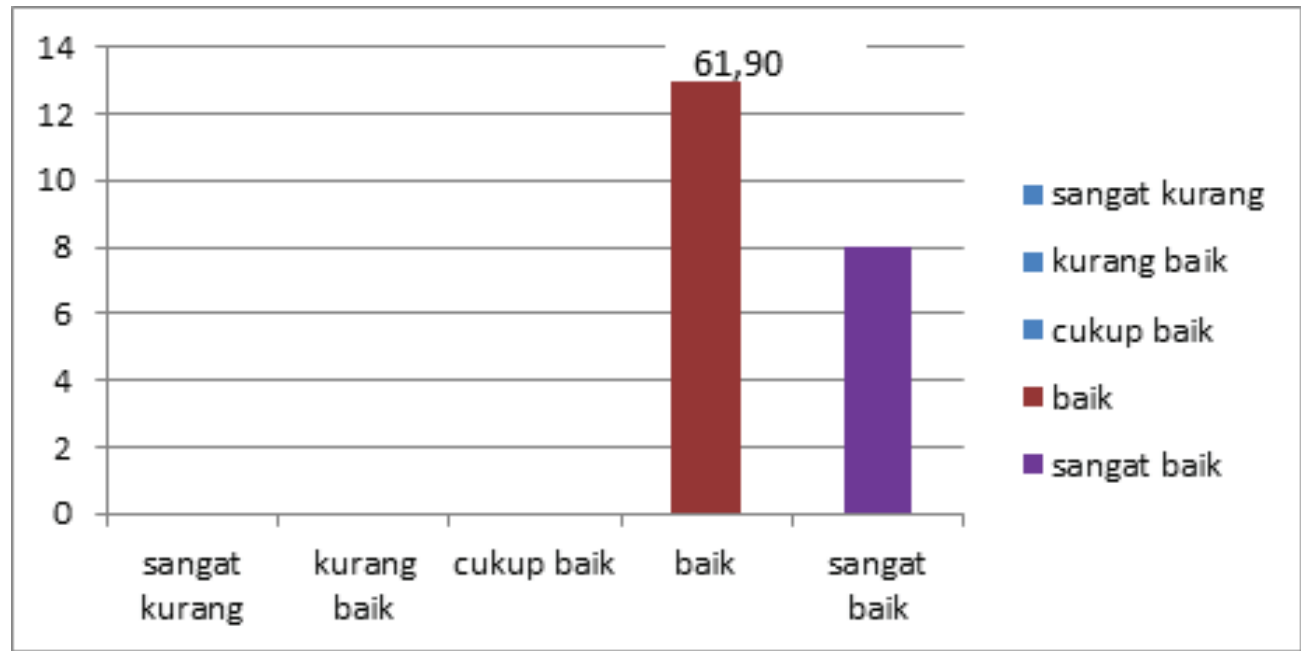

Figure 12: Histogram Aspect View of Media Expert Phase II.

While for programming aspect consisting of 10 items assessed "very good" with mean score 4,8 . For more details can be seen in the following table:

TABLE 10: Frequency of Programming Quality by Media Experts Phase II.

Kriteria
Very good
Good
Good enough
Less good
Very less good
Amount

\begin{tabular}{|c|c|}
\hline Frekuensi & $\%$ \\
\hline 8 & $80 \%$ \\
\hline 2 & $20 \%$ \\
\hline 0 & 0 \\
\hline 0 & 0 \\
\hline 0 & 0 \\
\hline 10 & 100 \\
\hline
\end{tabular}




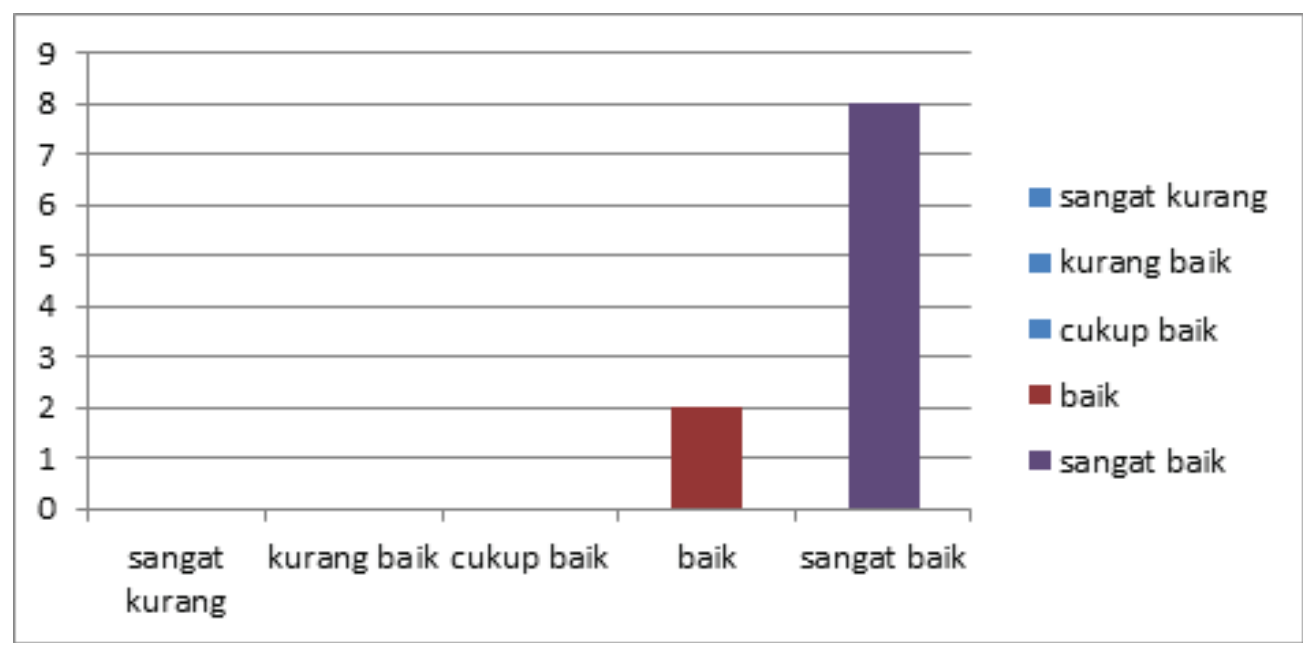

Figure 13: Histogram Aspects of Programming By Media Experts Phase II.

Assessment of the overall media learning expert being developed in stage II by the media expert can be seen in the following table:

TABLE 11: Product Quality Media Media Learning Media Stage II.

\begin{tabular}{|l|c|c|}
\hline Rated aspect & Average & Kriteria \\
\hline Display aspect & 4,38 & Very good \\
\hline Aspects of programming & 4,80 & Very good \\
\hline Average & 4,59 & Very good \\
\hline
\end{tabular}

Here is a histogram picture of the quality of learning media products by media experts stage II.

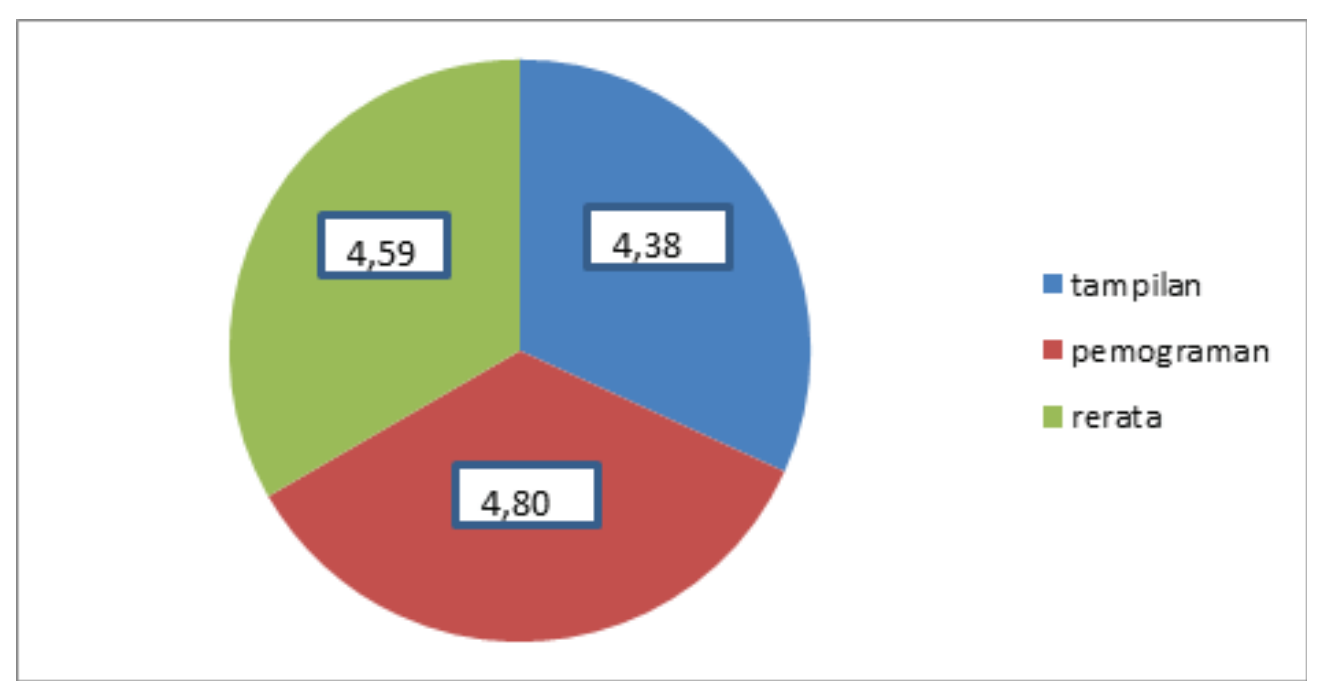

Figure 14: Histogram Product Quality Learning Media. 


\section{Media Expert Phase II}

Based on the above data it can be seen that the results of the assessment of media experts stage II on the quality of learning media products under development is included in the category of "very good". The average score on the aspect of display and programming aspect is 4.59 . The conclusion of this second stage that the media expert states that the products that have been developed can be tested in the field.

\section{Conclusions and Suggestions}

\subsection{Conclusion}

Based on the results of research and manufacture of interactive learning media products, it can be concluded as follows:

The quality of instructional media that we create according to the assessment of media experts is stage 1 of "good" category and stage 2 "very good". The average score from the assessment of media expert on revision 1 on the aspect of display of 3.52 and the average score from the assessment of media experts on the aspect pemograman of 3.5. The average score from the assessment of media experts on revision 2 on the aspect of display of 4.38 and the average score of the assessment of media experts on aspect pemograman of 4.8

\subsection{Suggestions}

This multimedia product is utilized in the learning process of Physical Education of Sport, and Health at SMP. This product can be used as a teacher for teaching materials in the classroom, and can also be used as a technology-based learning media.

\section{References}

[1] Jaliusril, Rayandra Asyhar, Hary Soedarto Harjono. (2012). Development of AudioVisual Media Short Running Learning For Students Smp. Tekno-Pedagogi Vol. 2 No. 1 Maret 2012: 1-21 ISSN 2088-205X. accessed on a date 5 March 2017.

[2] Kurnia, Dadeng (1987). Guidelines for Achieving Athletes. Diktat Jakarta.

[3] Adun Sudijandoko. (2010). Learning Effective and Qualified Physical Education. Journal of Indonesian Physical Education (Number 1 year 2008). Page 3-4. 
[4] Abdullah, Arma. (1981). Sports For Higher Education. Yogyakarta: Cultural Literature

[5] Kemp. Jerrold E, Morrison, Garry.R, Ros, Steven M. 1994. Dessigning Effetive Instruction. New York: Macmillan College Publishing.

[6] Asyhar, Rayandra. 2010. Creative develops Media Learning. Jakarta: Gaung Persada.

[7] Computer Research and Development Team. (2006). Animation Creation with Macromedia Flash Professional. Jakarta: Salemba Infotek.

[8] Sukintaka. (1992). Play Theory. Jakarta: Ministry of Education and Culture. Directorate General of Higher Education. Project for the Development of Education Personnel.

[9] Herka Maya Jatmika (2005). Utilization of Visual Media In Supporting Learning Physical Education in Elementary School. Journal of Physical Education Indonesia, Volume 3, No.1 Yogyakarta State University.

[10] Hamalik, Oemar. (1994). Education Media. The 7th. Bandung: Citra Aditya Bakti 